\title{
Teacher Assistant as One of the Supportive Measures of Inclusive Education of Pupils with Special Educational Needs
}

\author{
Eva Doležalová \\ Department of Special and Inclusive Education, Faculty of Education, Masaryk University, Brno, Czech Republic
}

\begin{abstract}
How to cite this paper: Doležalová, E. (2018). Teacher Assistant as One of the Supportive Measures of Inclusive Education of Pupils with Special Educational Needs. The Educational Review, USA, 2(5), 289-295. http://dx.doi.org/10.26855/er.2018.05.003
\end{abstract}

Corresponding author: Eva Doležalová, Mgr. et Mgr., Department of Special and Inclusive Education, Faculty of Education, Masaryk University, Brno, Czech Republic.

\begin{abstract}
Inclusive education is a current topic trying to implement the most suitable and effective techniques and strategies into the education process of all pupils. As one of the pillars of inclusive education is seen supportive measures whose main purpose is to build up sufficient support for all pupils with special educational needs. The research study analyses six articles dealing with the use of teacher assistants as a main supportive measure in the educational process. It is particularly focused on the identification and description of factors affecting the implementation of a support program, its benefits and deficiencies.
\end{abstract}

\section{Keywords}

Inclusive Education, Pupil with Special Educational Needs, Supportive Measures, Teacher Assistant, Mainstream School

\section{Introduction}

Education of pupils with special educational needs has long been a discussed topic that is a domain for a wide range of subjects whose main purpose is to set the appropriate conditions and follow the inclusive educational process in Czech mainstream schools. The inclusive way of thinking preceded a long period of "exclusion" during which pupils with disabilities were excluded from the educational system and "segregation" when pupils attending special schools were isolated from the rest of society. The significant benefit of this period was the first attempt to integrate pupils with disabilities into the educational process. These tendencies had been typical of the Czech educational system at the beginning of the 90th of 20th century, the turning point ending this period of total segregation of pupils with disabilities was Act No. 564/1990 Collection of Law, issued by Czech National Council about the national administration and autonomy in education. There was mentioned the possibility of integration of pupils with disabilities (Ainscow, Dyson, Booth \& Farrell, 2006; Bartoňová, Vítková et al. 2013; Edelsberger, 2000; Květoňová, Strnadová \& Hájková, 2012).

Inclusive education is constantly in the process of development. Inclusive efforts combine the elements of humanization and normalization. Persons with disabilities should have the right to full-fledged life in their natural environment, as well as the right to work and social application. The basic idea of humanization is the equal reception of all persons. Only in the case of a positive impact on the integrating member of the company can this process be classified as positive. In particular, special ped-agogy which identifies factors for successful inclusion seeks to achieve this goal (Ainscow, Dyson, Booth \& Farrell, 2006; Kaleja, 2014; Valenta \& Müller, 2013). 
The reform No. 82/2015 of the Act No. 564/1990 Coll., on Pre-School, Basic, Secondary, Tertiary Professional and Other Ed-ucation (the Education Act) introduced new supportive measures for children with special educational needs. Special educa-tional needs are understood as specific support for children or pupils with disabilities. The required amendment supports the implementation of inclusive education into the Czech educational system and defines a pupil with special educational needs: "a pupil with special educational needs is defined as someone who needs supportive measures in order to fulfil his/her educational abilities and rights" (Decree No. 82/2015 Coll., § 16).

Supportive measures have become key elements of effective inclusive education. "By supportive measures we understand necessary adjustments in education and educational services which correspond with the health conditions, environment and living conditions of the child, pupil or student. Children, pupils and students have a right to free supportive measures provided by the school or school facilities" (Decree No. 82/2015 Coll., § 16a).

Supportive measures provide required tools to adapt the teaching process to pupils. These measures should fit the particular needs of pupils. Supportive measures are divided into 5 stages according to the seriousness (organizational, educational and financial demands). From the second to the fifth grade, experts in school counselling facilities examine the pupil and conse-quently, it is determined diagnosis and recommended the supportive measures for the school. For the first grade of supportive measures, the teaching methods and assessment are individually adjusted to pupil's difficulties by his school. The school counselling facilities provide counselling assistance to the pupil or his legal guardian on the basis of his own request or decision of a public authority. After receiving the final recommendation from the school counselling facilities, a pupil or his guardian may apply for its revision within 30 days from the date the recommendation received (Decree No. 82/2015 Coll., § 16, 16a, 16b; Lechta et al. 2016; Michalík, Baslerová, Felcmanová et al. 2015; Michalík, Baslerová, Hanák et al. 2012).

Supportive measures are newly treated with Decree No. 27/2016 Coll. On the education of pupils with special educational needs and gifted pupils according to $\S 16$ of the reformed Education Act that came into the force on 1st September 2016. $\S 2$ focuses on the explanation of supportive measures referring to the first supplement of this Decree. There are described in detail recommended supportive measures and its implementation into the educational process. Further, $\S 5$ defines the use of a teacher assistant in the teaching process. It says that one teacher assistant provides support to four pupils in a class, department or study group. It is always essential to modify teaching methods according to the recommendations in terms of the special needs of pupils in a class (Decree No. 27/2016 Coll., § 2, 5).

Ministry of Education, Youth and Sport issued the following documents on the website: National Action Plan for Inclusive Education, Comments to the overview of supportive measures, Three-staged model of care, Methodology for special education teachers and assistant teachers. Legislative changes related to the education of pupils with special educational needs have become an essential basis for the implementation of inclusive education in the Czech Republic. A range, formation and application of supportive measures play a crucial role in the educational process as well as the mutual cooperation of main participants (Breyer, Fohrer, Goschler, Heger, Kießling \& Ratz, 2012; Čadová et al. 2015; Kaleja ed. 2014; Křivohlavý, 2009; Lazarová, Hloušková, Trnková, Pol \& Lukas, 2015; Lukášová, 2010; Valenta \& Müller, 2013).

\section{Methodology}

The main purpose of the study is to explore and describe the main factors affecting the use of teacher assistants as a supportive measure in the process of inclusive education of pupils with special educational needs and identify their benefits and deficiencies. Two additional research questions were included: What factors affect the use of teacher assistants as a supportive measure in the process of inclusive education? How do authors of partial research projects evaluate the effectiveness of the role of teacher assistants as a supportive measure in the process of inclusive education? 
Subsequently, literature analyses focused on studies published by foreign authors who were interested in the issue of inclusive education, supportive measures and especially in the use of a teacher assistant. The literature review was conducted on 14th August 2016. It covered the database EBSCO and used keywords: inclusive education or inclusion, teacher assistant, main-stream school. A total number of 28 resources were identified. After the first selection, the criteria were further narrowed to available full text and peer-reviewed journals published in academic periodicals during the period 2004 - 2016. Based on these criteria, only 6 studies fitted the required criteria and were chosen for the final literature analyses. The following table provides the general overview of the selected studies.

Table 1. The overview of the selected studies.

\begin{tabular}{|c|c|c|c|}
\hline Title & Author, year & Research method & Topic of research \\
\hline $\begin{array}{l}\text { Factors associated with the effective } \\
\text { inclusion of primary-aged pupils with } \\
\text { Down's syndrome }\end{array}$ & $\begin{array}{l}\text { Fox, Farrell \& Davis, } \\
\qquad 2004\end{array}$ & Case study & $\begin{array}{l}\text { Identification of key factors associated with the effec- } \\
\text { tive inclusion }\end{array}$ \\
\hline $\begin{array}{l}\text { Educational psychology and the } \\
\text { effectiveness of inclusive } \\
\text { education/mainstreaming }\end{array}$ & Lindsay, 2007 & Research study & $\begin{array}{c}\text { Effectiveness of inclusive education } \\
\text { with examination of evidence on the supportive pro- } \\
\text { cesses }\end{array}$ \\
\hline $\begin{array}{l}\text { The work of classroom assistants in special } \\
\text { and mainstream education in Finland } \\
\text { The impact of teaching assistants on }\end{array}$ & Takala, 2007 & Case study & $\begin{array}{l}\text { The role and function of teacher assistants in inclusion } \\
\text { and specialist classroom }\end{array}$ \\
\hline $\begin{array}{c}\text { improving pupils' academic achievement in } \\
\text { mainstream schools: a review of the } \\
\text { literature }\end{array}$ & $\begin{array}{l}\text { Farrell, Alborz, Howes } \\
\quad \& \text { Pearson, } 2010\end{array}$ & Research study & $\begin{array}{c}\text { The impact of teacher assistants on pupils' academic } \\
\text { achievement in mainstream schools }\end{array}$ \\
\hline $\begin{array}{l}\text { The deployment, training and teacher } \\
\text { relationships of teaching assistants } \\
\text { supporting pupils with autistic spectrum } \\
\text { disorders (ASD) in mainstream secondary } \\
\text { schools }\end{array}$ & $\begin{array}{l}\text { Symes \& Humphrey, } \\
\qquad 2011\end{array}$ & Case study & The impact of teacher assistants in classrooms \\
\hline $\begin{array}{l}2014 \text { Code of Practice: how research } \\
\text { evidence on the role and impact of teaching } \\
\text { assistants can inform professional practice }\end{array}$ & Webster, 2014 & Case study & $\begin{array}{l}\text { The role and impact of teacher assistants on inclusion of } \\
\text { pupils with special educational needs in mainstream } \\
\text { classroom }\end{array}$ \\
\hline
\end{tabular}

\section{Literature Review}

After reviewing studies related to a context of the study, the author ended up having 6 articles published during the period 2004 - 2016. All these studies were published in the English language. Five of the selected studies were conducted in Great Britain and one study came from Finland. This study provides an overview of four case studies and two research studies.

A case study by Fox, Farell \& Davis (2004) examined the factors associated with the effective inclusive education of pupils with Down's syndrome (DS). The research focused on the inclusion of 18 pupils with DS. Research methods of observation and interview were used to explore the support for a child with DS in mainstream schools in different locations in Great Britain. The partial aims were to determine the methods used for the successful deployment of support and key factors associated with the effectiveness of inclusive education.

Geoff (2007) dealt with the review of published journals on the topic of the effectiveness of inclusive education. The author's analysis covered all studies published in eight journals from the field of special education published 2001-2005. As one of the reported themes, the author explored the factors including the use of teacher assistants in the process of inclusion. Following the research evidence, the role of teacher assistants was found unclear and often left to schools to determine their workload.

A Finish study by Takala (2007) compared the workload of assistants in mainstream and special schools. The case study described the work of 14 teacher assistants. Based on the observation and interview methods, the role and work of teacher 
assistants were found extremely effective for inclusive education of pupils with special education needs.

Another research study discussed the impact of teacher assistants on improving pupils' academic achievement in mainstream schools (Farrell, Alborz, Howes \& Pearson, 2010). The authors selected 13 studies focused on the impact of teacher assistants on school attainments of pupils. The evidence supported the view that the presence of teacher assistants in mainstream classes may have a positive impact on the achievements of all pupils, and not only on pupils with identified difficulties.

Symes \& Humphrey (2011) utilized an interview as a method for qualitative research to explore the use of teacher assistants to support pupils with autistic spectrum disorders in mainstream secondary schools. Fifteen assistants working in these schools participated in the study. Following the collected data, a lack of available time for joint planning between teachers and teacher assistants was reported as a factor having a negative effect on the process of inclusion.

Webster (2014) reflected on the role and impact of teacher assistants on pupils with special educational needs during the inclusion process into mainstream schools. Based on observing pupils and interviewing teachers, teacher assistants and parents, subsequent qualitative and quantitative analyses of these collected data defined significant deficiencies in the de-ployment of inclusive education programs.

\section{Data Analysis}

The research study deals with the use of teacher assistants as one of the supportive measures in the inclusive education of pupils with special educational needs. There are identified factors associated with the deployment of teacher assistants and evaluated the effectiveness of the role of assistants in the process of inclusive education. Based on these criteria, only 6 studies fitted the context and were selected for the final literature analysis. The study provides an overview of four case studies and two research studies.

The selected studies point out to the role and function of teacher assistants representing the key factor in inclusive education and to the form of the support providing to pupils with special educational needs.

The teacher assistant is an employee of the school thus money is the determinative factor affecting the establishment of this job. The amount of support provided is not based on detailed individual assessments of children's needs, it is tended to be associated with the school management and received funding (Fox, Farrell \& Davis, 2004).

The sustained practice is a one-to-one model of interaction in mainstream schools; one teacher assistant provides his support to one child with special educational needs. An increase in the number of working hours means more funding for schools, which is likely to cause serious financial problems. Moreover, the assumption that the increased number of lessons which teacher assistants spend with pupils will have a positive effect on their academic progress is a common fallacy (Webster, 2014). The rapid growth in the number of teacher assistants does not result in a successful learning experience (Farrell, Alborz, Howes \& Pearson, 2010).

Compared to other pupils in mainstream schools, pupils with special educational needs spend less time in lessons and their educational process is strongly affected by the presence of teacher assistants. Mostly teacher assistants support just one child in a class, this one-to-one interaction exceeds the interaction of the pupil with teachers and peers (Webster, 2014). The excessive adult proximity causes a barrier between pupils with special educational needs and their classmates called "artificial separation" (Takala, 2007).

Another area of concern is the fact that the role of teacher assistants is not well-defined, which is likely to be confusing for pupils in a class (Symes \& Humphrey, 2011). The most central part of teacher assistants' work is assisting individual pupils, however, more time assistants spend waiting for teachers' instructions. Due to the lack of time for joint lesson planning, assis-tants have to listen carefully each lesson in order to know what to do. Because of these deficiencies, 
misunderstandings arise between teachers and assistants. Effective lessons are associated with planning; teacher assistants need to understand the aims of chosen activities. Assisting teachers is an essential part of inclusion of pupils with special educational needs (Takala, 2007). According to the study published by the researchers Fox, Farrell \& Davis (2004), the assistants supported other pupils had a significantly negative impact on academic achievement of pupils with Down's syndrome, but nevertheless, the use of peer support improved the social interaction. The first years of compulsory education, teacher assistants have a more favorable impact on pupils with special educational needs than in the following years (Takala, 2007).

The extent to which teacher assistants participate in the educational process is still changing. The main practice providing by teacher assistants has been direct support for pupils with special educational needs including direct teaching or academic skills; supporting pupils with challenging behavior, facilitating interaction with other pupils, providing personal care and self-help skills (Geoff, 2007).

Teacher assistants often have the main responsibility for the education of pupils with special educational needs; in particular, pedagogical decision making about lesson plans, homework correction etc. (Webster, 2014). Findings indicate that the pres-ence of teacher assistants has a positive impact on small groups of pupils because it is easier to respond to specific needs of individual children. These small groups get adequate support and information needed to complete assignments (Farrell, Alborz, Howes \& Pearson, 2010).

Teachers and teacher assistants work together to support children with special educational needs. The role and responsibilities of teachers and teacher assistants are likely to be confusing. Teachers are often criticized for not being highly involved in the educational process of children with special educational needs and teacher assistants take over the role of teachers. Despite teacher assistants' training and experience, they are often positioned as "the expert on the child with special educational needs" by teachers themselves (Webster, 2014). The majority of teacher assistants work just with one pupil in a variety of lessons (Symes \& Humphrey, 2011). In marked contrast, there are many examples of teachers and teacher assistants working in close collaboration; they plan meetings to share information about pupils and to prepare lesson plans. The arrangement helps assistants to feel being an internal part of a school team and leads to effective teamwork. Based on the results of studies, class teachers do not experience overload if there is a teacher assistant in a class, which increase teachers' productivity and job satisfaction. Nevertheless, it is essential to specify work tasks for both teachers and teacher assistants (Farrell, Alborz, Howes \& Pearson, 2010).

Regarding learning support of teacher assistants, teachers prefer assistants working among older than younger pupils and as-sisting in special schools than in mainstream schools (Takala, 2007). Further, the process of inclusive education is more likely to be successful if class teachers take the central role in the class management and organization of lesson activities for children with special educational needs (Fox, Farrell \& Davis, 2004). A clear definition of roles and cooperation among staff members in schools eliminates work chaos in the process of education (Takala, 2007).

The collaboration between teachers and teacher assistants is a key element of inclusion. Lack of communication and time is one of the most often problems of the inclusive education (Symes \& Humphrey, 2011). It is extremely important to advise teachers with little or no experience how to work with teacher assistants to build a successful team (Farrell, Alborz, Howes \& Pearson, 2010). Any insufficient collaboration contributes to a higher level of anxiety of all involved in working with children with special educational needs

Although the use of teacher assistants has already been well-established lack of adequate training still concerns inclusion (Geoff, 2007). Little training and no practical experience of teacher assistants are barriers to promote effective inclusion edu-cation (Symes \& Humphrey, 2011). Trained and supported teacher assistants have a positive impact on all pupils in the class (Farrell, Alborz, Howes \& Pearson, 2010). According to the study published by the researchers Symes \& 
Humphrey (2011), inclusive education has been sufficiently realized in practice, however, social support has not been effective enough.

\section{Conclusion}

Supportive measures are key elements of inclusive education. One of the most often used supportive measures is the presence of a teacher assistant in a class. For the research study, literature analyses focused on studies published by foreign authors who were interested in the issue of inclusive education, supportive measures and especially in the use of a teacher assistant.

The authors of selected studies defined factors affecting the role of teacher assistants. They mentioned the lack of funding and the not well-defined role of teacher assistants which can be confusing. Further, the insufficient collaboration between teachers and teacher assistants contribute to a higher level of anxiety of all involved in working with children with special educational needs. As the last barrier to inclusive education, the researchers pointed out little training and no practical experience of teacher assistants.

Based on the findings, there has not been described a universal procedure for effective inclusion. The alternative arrangements could be the identification of concerns associated with inclusion and the effort to implement effective strategies providing support for all involved in the process of inclusive education.

\section{References}

Ainscow, M., Dyson, A., Booth, T., \& Farrell, P. (2006). Improving Schools, Developing Inclusion. London: Routledge.

Bartoňová, M., Vítková, M. et al. (2013). Vzdělávání se zaměřením na inkluzivní didaktiku a vyučování žáků se speciálními vzdělávacími potřebami ve škole hlavního vzdělávacího proudu. Brno: Masarykova univerzita.

Breyer, C., Fohrer, G., Goschler, W., Heger, M., Kießling, Ch., \& Ratz, Ch. (2012). Sonderpädagogik und Inklusion. Oberhausen: ATHENA - Verlag.

Čadová, E. et al. (2015). Katalog podpůrných opatření pro žáky s potřebou podpory ve vzdělávání z důvodu tělesného postižení nebo závažného onemocnění. Olomouc: Univerzita Palackého.

Edelsberger, L. a kol. (2000). Defektologický slovník. Jinočany: H\&H.

Farrell, P., Alborz, A., Howes, A., \& Pearson, D. (2010). The Impact of Teaching Assistants on Improving Pupils' Academic Achievement in Mainstream Schools: A Review of the Literature. Educational Review, 62(4), 435-448.

Fox, S., Farrell, P., \& Davis, P. (2004). Factors Associated with the Effective Inclusion of Primary-Aged Pupils with Down's Syndrome. British Journal of Special Education, 31(4), 184-190.

Kaleja, M. (ed.) (2014). Inkluzivní dimenze primárního a sekundárního vzdělávaní ve speciální pedagogice. Ostrava: Ostravská univerzita.

Křivohlavý, J. (2009). Psychologie zdraví. Praha: Portál.

Květoňová, L., Strnadová, I., \& Hájková, V. (2012). Cesty k inkluzi. Praha: Karolinum.

Lazarová, B., Hloušková, L., Trnková, K., Pol, M., \& Lukas, J. (2015). Řízení inkluze ve škole. Brno: Masarykova univerzita.

Lechta, V. et al. (2016). Inkluzivní pedagogika. Praha: Portál.

Lindsay, G. (2007). Educational Psychology and the Effectiveness of Inclusive Education/Mainstreaming. British Journal of Educational Psychology, 77(1), 1-24.

Lukášová, H. (2010). Kvalita života dětí a didaktika. Praha: Portál.

MŠMT. (2015). Zákon č. 82/2015 Sb., kterým se mění zákon č. 561/2004 Sb., o předškolním, základním, středním, vyšším odborném a jiném vzdělávání (školský zákon), ve znění pozdějších předpisů, a některé další zákony. Retrieved from http://www.nuv.cz/uploads/NZZ2/Novela_Sbirka.docx

MŠMT. (2016). Vyhláška č. 27/2016 Sb., o vzdělávání žáků se speciálními vzdělávacími potřebami a žáků nadaných. Retrieved from http:// www.zakonyprolidi.cz/cs/2016-27

Michalík, J., Baslerová, P., Felcmanová, L. et al. (2015). Katalog podpůrných opatření pro žáky s potřebou podpory ve vzdělávání z důvodu zdravotního nebo sociálního znevýhodnění: obecná část. Olomouc: Univerzita Palackého.

Michalík, J., Baslerová, P., Hanák, P. et al. (2012). Katalog posuzování míry speciálních vzdělávacích potřeb - část I.: hmotněprávní a 
procedurální standardy, dokumentace a vybrané vzory v činnosti SPC. Olomouc: Univerzita Palackého.

Symes, W., \& Humphrey, N. (2011). The deployment, training and teacher relationships of teaching assistants supporting pupils with autistic spectrum disorders (ASD) in mainstream secondary schools. British Journal of Special Education, 38(2), 57-64.

Takala, M. (2007). The Work of Classroom Assistants in Special and Mainstream Education in Finland. British Journal of Special Education, 34(1), 50-57.

Valenta, M., \& Müller, O. (2013). Psychopedie: teoretické základy a metodika. Praha: Parta.

Webster, R. (2014). 2014 Code of Practice: How Research Evidence on the Role and Impact of Teaching Assistants Can Inform Professional Practice. Educational Psychology in Practice, 30(3), 232-237. 